\title{
Xyris serrana (Xyridaceae), a new species endemic to the Campos de Cima da Serra, southern Brazil
}

\section{Eduardo Damasceno Lozano* (1), Maria das Graças Lapa Wanderley² (1) and Paulo Takeo Sano ${ }^{1}$ (1)}

Received: August 31, 2020

Accepted: March 9, 2021

\begin{abstract}
A new species of Xyris endemic to Southern Brazil is described. Xyris serrana is placed in X. sect. Nematopus, which is characterized by having basal, suprabasal, or central placentation. The new species is known from few samples from the summits of Serra Geral, in Santa Catarina State. According IUCN criteria, the conservation status of the species is evaluated as Data Deficient. Xyris serrana is morphologically similar to X. neglecta due to both having narrowly flattened blades and young bracts with villous-ciliate margins, but differs by its yellowish-brown sheaths, blackish-brown bracts with a narrow macula, and lateral sepals with reddish trichomes. A description, illustration, distribution map, and taxonomic comments are provided.
\end{abstract}

Keywords: neotropical flora, subtropical highland grasslands, Nematopus, Xyrid clade

\section{Introduction}

Xyris is the largest genus of Xyridaceae and comprises nearly 420 species. The Neotropical region is one of the genus' center of diversity, housing over 200 species (Campbell 2004). In Brazil, ca. 180 species are recorded (Flora do Brasil 2020 2020), being 27 listed in the Brazilian Flora Red List (Wanderley et al. 2013). The genus is characterized by its pedunculate spikes, usually longer than the leaves, and yellow or white, usually showy corolla (Lozano et al. 2018).

The Campos de Cima da Serra region represents Southern Brazil's Subtropical Highland Grasslands (Iganci et al. 2011). This vegetation is nested within the Atlantic Forest biome (IBGE 2004) distributed in the three States of Southern Brazil, covering approximately 1,374,000 ha (Boldrini et al. 2009; Iganci et al. 2011). It has a $23.5 \%$ endemism rate amongst flowering plants, which corresponds to about
$3.5 \%$ of the total endemic plants of the Atlantic Forest biome (IBGE 2004; Stehmann et al. 2009; Plá et al. 2020).

As Iganci et al. (2011) stated, the eastern boarder of the plateau (i.e., from Campos dos Padres and Serra do Corvo Branco, in the State of Santa Catarina, to Serra da Rocinha and Cambará do Sul, in the State of Rio Grande do Sul), presents high rate of diversity of endemic flowering plants, which was observed by Külkamp et al. (2018). During our studies of Xyridaceae from the Campos de Cima da Serra region, a new species, Xyris serrana, was discovered and is here described and illustrated.

\section{Materials and methods}

The description and comments are based on the specimens collected during field trips, and the exsiccates are from FLOR, ICN, MBM, RB, and SPF herbaria (acronyms

1 Departamento de Botânica, Instituto de Biociências, Universidade de São Paulo, 05508-900, São Paulo, SP, Brazil

2 Núcleo de Pesquisas Curadoria do Herbário, Instituto de Botânica, 04301-902, São Paulo, SP, Brazil

*Corresponding author: eduardo_dl11@hotmail.com 
according to Thiers (2020, continuously updated). Morphological terminology follows Wanderley (2011) and the taxonomic species concept follows Nixon \& Wheeler (1990). Photos of the morphological details were captured under a stereomicroscope Digilab DI-106T.

\section{Results}

\section{Taxonomic treatment}

\section{Xyris serrana E.D.Lozano \& Wand. sp. nov.}

Type: BRAZIL. Santa Catarina: Bom Jardim da Serra, PARNA de São Joaquim, cume do Morro da Igreja, $28^{\circ} 07^{\prime} 36.5^{\prime \prime} \mathrm{S}-49^{\circ} 28^{\prime} 50.6^{\prime \prime} \mathrm{W}, 16$ Dec 2017 [f.], E.D. Lozano \& B.K. Canestraro 4075 (Holotype: MBM!; isotypes: FLOR!, ICN!, RB!, SPF!). (Figs. 1 and 2).

Herbs perennial, cespitose, with a soft base. Roots slender, fibrous. Rhizome erect to horizontal, internodes short, 1-4 mm long. Leaves $16-42.5 \mathrm{~cm}$ long, spirallyalternate, erect; sheaths $4.5-8 \times 0.6-0.9 \mathrm{~cm}$, widely dilated towards the base, with hyaline mucilage, yellowish-brown, smooth, margin hyaline, brown to yellow, glabrous; blades $11.5-34.5 \times 0.05-0.13 \mathrm{~cm}$, narrowly flattened, slightly twisted, smooth, green, margin glabrous, apex acuminate. Ligule present, ca. $1 \mathrm{~mm}$ long. Spathes $6-8 \times 0.32-0.46$ $\mathrm{cm}$, yellowish-brown, ecarinate, margin hyaline, blade short, 1.6-4.5 mm long. Peduncles 27-44.5 × 0.08-0.11 $\mathrm{cm}$, subterete, 1-costate, green, glabrous. Spikes 8.1-10.1 $\times 4.6-6.8 \mathrm{~mm}, 10-14$ flowered, ellipsoid, bracts blackishbrown at middle, margin light brown, ecarinate, with a narrow macula, light brown, margin short-lacerate, villous-ciliate when young, trichomes blackish-brown; sterile bracts $6-8$ per spike, $4.8-6.4 \times 3.9-4.7 \mathrm{~mm}$, ovate; fertile bracts $10-14$ per spike, $7.8-8.6 \times 5.7-5.9 \mathrm{~mm}$, obovate. Flowers with dorsal sepal cucullate, membranous, reddish, caduceus at anthesis; lateral sepals $6.9-8 \mathrm{~mm}$ long, included, free, oblanceolate, subequilateral, apex acuminate, keel narrow, lacerate-fimbriate at middle, villous-ciliate at middle towards the apex, trichomes reddish; petals yellow, lobe ca. $5.4 \times 4.9 \mathrm{~mm}$, obovate, margin erose; androecium yellow, staminodes bifid, ca. 2 $\mathrm{mm}$ long, the branches densely penicillate, stamens ca. $3.2 \mathrm{~mm}$ long, anthers oblong; gynoecium yellow, style ca. $6 \mathrm{~mm}$ long, branches ca. $3 \mathrm{~mm}$ long, stigma dilated; central placentation, ovules with long funicles. Capsules 4.9-5.6 × 2.1-2.3 mm, obovoid. Seeds ca. $1.2 \times 0.4 \mathrm{~mm}$, fusiform, reddish-brown, opaque to faintly translucent, ribbed, apex apiculate, translucent.

Distribution and habitat: Xyris serrana is known from few samples from the summits of Serra Geral, in Santa Catarina State (Fig. 3), one in the São Joaquim National Park, and another in a private area in the Campo dos Padres region. According to Külkamp et al. (2018), the São Joaquim National Park is the Conservation Unit with the most significant number of endemic species (35) in the Campos de Cima da Serra. The presence of the $X$. serrana reinforce the importance of this unit for species conservation.

Xyris serrana grows in the moist grasslands over histosols with the surrounding vegetation rarely exceeding $50 \mathrm{~cm}$ in height.

Conservation status: The distribution and size population of $X$. serrana are still poorly known to adequately assess its conservation status under the IUCN (2012) categories and criteria. Thus, Xyris serrana is here categorized as Data Deficient (DD), until more information from the species becomes available. However, the Campo do Padres, one of the areas where the species was recorded, suffers for plausible threats (e.g., destruction of natural vegetation for pine plantation) compromising the maintenance of species.

Phenology: Xyris serrana blooms from December to January and bears fruits immediately after flowering.

Etymology: The specific epithet refers to the species occurrence site in the Campos de Cima da Serra region, between the States of Santa Catarina and Rio Grande do Sul.

Paratypes: BRAZIL. Santa Catarina: Bom Jardim da Serra, Morro da Igreja, próximo ao estacionamento $28^{\circ} 07^{\prime} 36.6^{\prime \prime}$ S - 49 28'58.5” W, 27 Apr 2016 [fr.], E.D. Lozano \& V. Ariati 3358 (MBM!, RB!, SPF!). Urubici, topo do Morro da Igreja, 13 Dec 2016 [f.], J. Külkamp et al. 204 (ICN!); Campo do primeiro platô do Morro Boa Vista, Campo do Padres 27'56'39" S 49²0'47” W, 08 Jan 2006, [f.]., A. Zanin et al. 910 (FLOR); Fazenda do Sr. Arno Philippe, campo entre a casa da fazenda e o Morro dos Padres, 07 Dec 2006, [fl.], A. Zanin et al. 1270 (FLOR).

\section{Discussion}

Xyris serrana belongs to the X. sect. Nematopus Seub., the largest section of the genus, which is characterized by its basal, suprabasal, or central placentation (Wanderley 2011). Morphologically it is similar to X. neglecta, as both have narrowly flattened blades and the young bracts with villous-ciliate margins.

Xyris serrana differs from $X$. neglecta by the yellowishbrown sheaths, blackish-brown bracts with a narrow macula, and lateral sepals with reddish trichomes. A comparison between both species is presented in Table 1 .

The occurrence of blackish-brown bracts in X. serrana may be a morphological pattern related to the altitude species from Atlantic Forest biome, since $X$. fusca L.A.Nilsson, X. itatiayensis (Malme) Wand. \& Sajo, and $X$. wawrae Heimerl., which are endemic to the altitudinal grasslands from Serra da Mantiqueira, also show this feature. However, its evolutionary or ecological meaning demands further studies. 


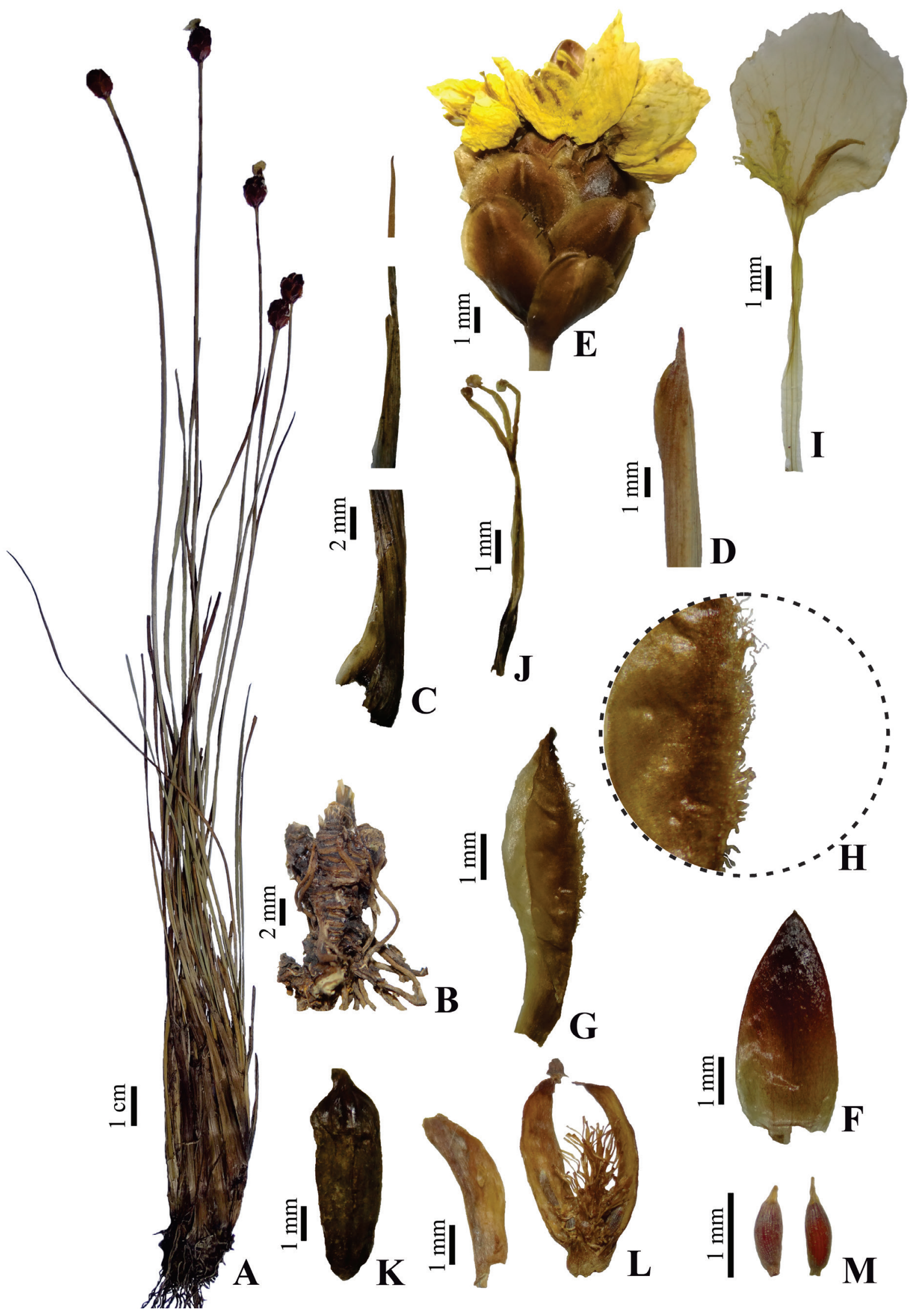

Figure 1. Xyris serrana morphological details: A. habit. B. rhizome. C. transversal leaf sections. D. apex of spathe. E. spike. F. dorsal sepal. G. lateral sepal. H. indument detail of lateral sepal. I. petal with stamen and staminode. J. gynoecium. K. capsule. L. capsule open, showing central placentation. M. seeds. (based on E.D. Lozano \& V. Ariati 3358 and E.D. Lozano \& B.K. Canestraro 4075). 
Table 1. Comparison of Xyris serrana and X. neglecta L.A.Nilsson.

\begin{tabular}{|c|c|c|}
\hline Leaf-sheaths & Xyris serrana & Xyris neglecta \\
\hline Leaf-blades & Yellowish-brown & Light brown to dark reddish-brown \\
\hline Bracts & Smooth & Usually transverse-rugose, rarely smooth \\
\hline Bract's macula & Blackish-brown & Brown \\
\hline Lateral sepals' trichomes & Narrow & Lanceolate \\
\hline
\end{tabular}
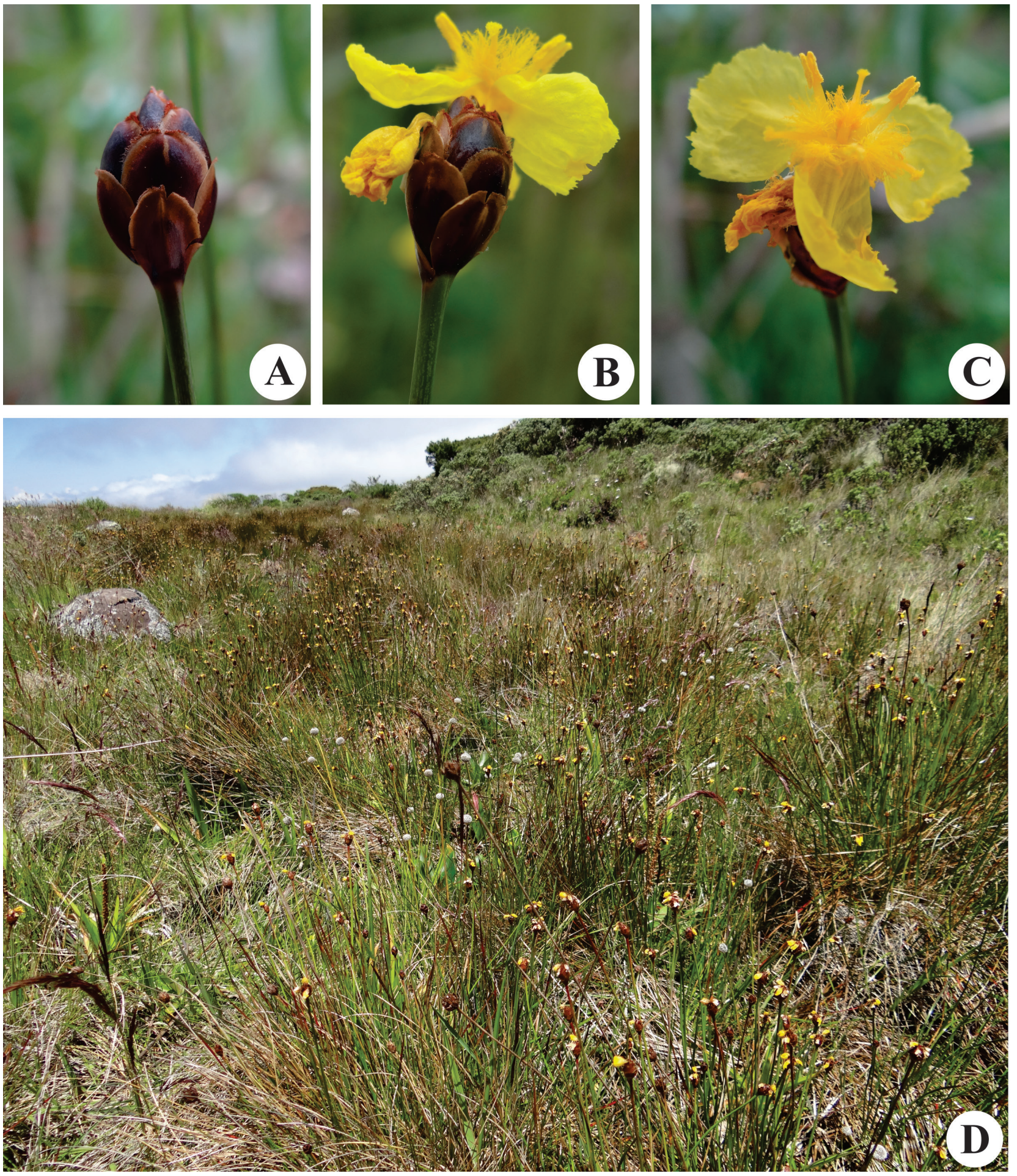

Figure 2. Xyris serrana: A. young spike. B. mature spike. C. flower. D. habitat. (based on E.D. Lozano \& V. Ariati 3358). Photos by E.D. Lozano. 


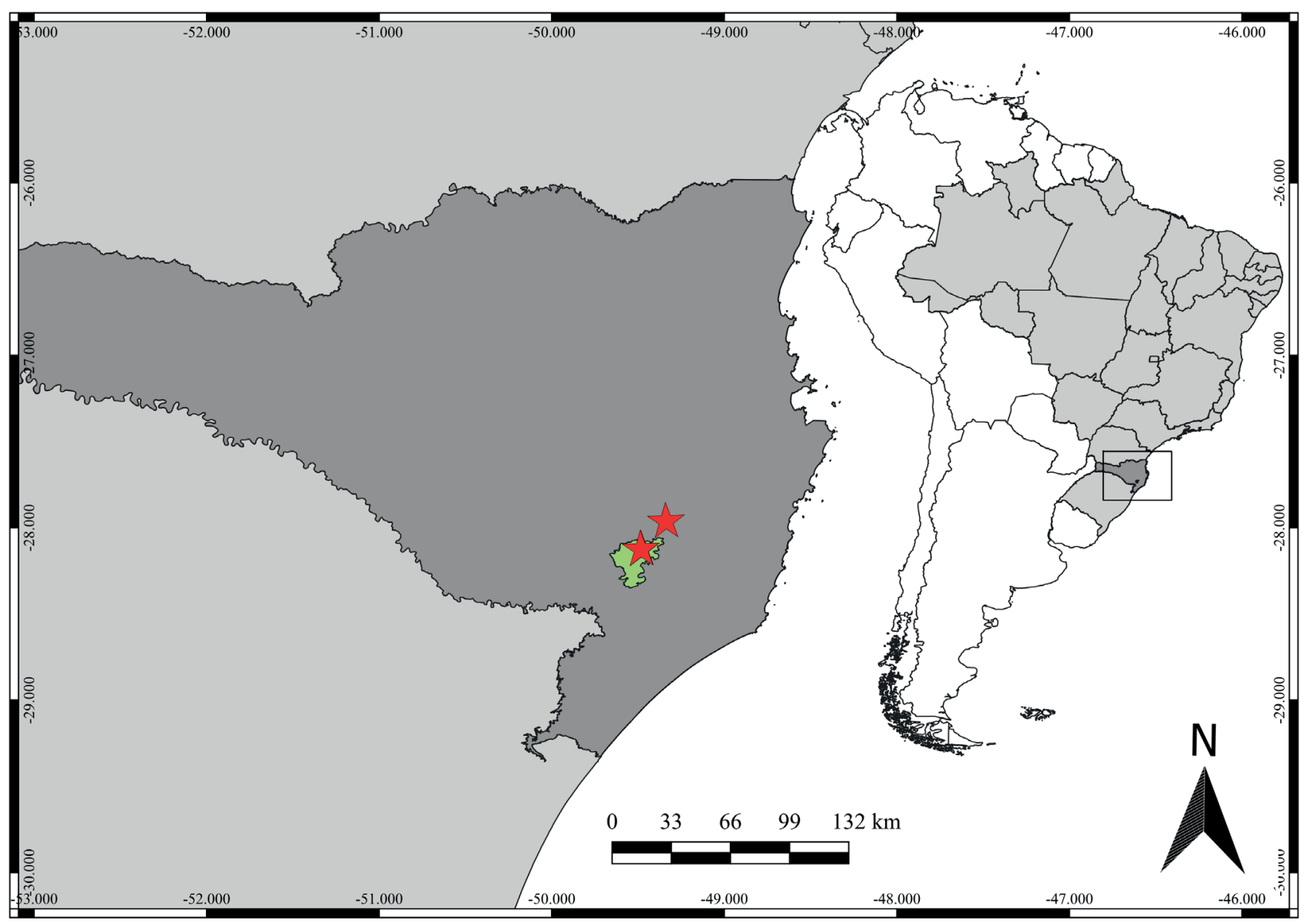

Figure 3. Distribution of Xyris serrana. The light green area represents the São Joaquim National Park. In dark grey, is Santa Catarina State.

\section{Acknowledgements}

We thank the CNPq - Conselho Nacional de Desenvolvimento Científico e Tecnológico for providing financial support (Proc. 168086/2017-4 and Proc. 310331/2019-6). To Dr. Marcio Roberto Costa Martins for his assistance with the assessment of risk of extinction under the criteria of IUCN.

\section{References}

Boldrini II, Eggers L, Mentz LA, et al. 2009. Flora. In: Boldrini I. (ed.) Biodiversidade dos Campos do Planalto das Araucárias. Brasília, Ministério do Meio Ambiente. p. 39-94.

Campbell LM. 2004. Xyridaceae. In: Smith N, Mori SA, Henderson A, Stevenson DW, Heald SV. (eds.) Flowering Plants of the Neotropics. Princeton, NJ, Princeton University Press. p. 492-493.

Flora do Brasil 2020. 2020. Xyridaceae. Jardim Botânico do Rio de Janeiro. http://floradobrasil.jbrj.gov.br/. 21 May 2020.

IBGE - Instituto Brasileiro de Geografia e Estatística. 2004. Mapa de Biomas do Brasil, primeira aproximação. Rio de Janeiro, IBGE. https:// biblioteca.ibge.gov.br/visualizacao/livros/liv101588.pdf

IUCN - International Union for Conservation of Nature. 2012. IUCN Red List Categories and Criteria: Version 3.1. 2nd. edn. Gland, Switzerland, Cambridge, UK, IUCN.
Iganci JRV, Heiden G, Miotto STS, Pennington RT. 2011. Campos de Cima da Serra: the Brazilian Subtropical Highland Grasslands show an unexpected level of plant endemism.Botanical Journal of the Linnean Society 167: 378-393.

Külkamp J, Heiden G. Iganci JRV. 2018. Endemic plants from the Southern Brazilian Highland Grasslands. Rodriguésia 69: 429-440.

Lozano ED, Smidt EC, Wanderley MGL. 2018. Estudos taxonômicos das Xyridaceae no estado do Paraná, Brasil. Rodriguésia 69: 1737-1769.

Nixon KC, Wheeler QD. 1990. An amplification of the phylogenetic species concept. Cladistics 6: 211-223.

Plá C, Külkamp J, Heiden G, Lughadha EN, Iganci JRV. 2020. The importance of the Brazilian Subtropical Highland Grasslands evidenced by a taxonomically verified endemic species list. Phytotaxa 452: 250-267.

Stehmann JR, Forzza RC, Salino A, Sobral M, Costa DP, Kamino LHY. 2009. Plantas da Floresta Atlântica. Rio de Janeiro, Jardim Botânico do Rio de Janeiro . https://www.researchgate.net/profile/LuciaLohmann/publication/236885151_Plantas_da_Floresta_Atlantica_ Bignoniaceae/links/00b7d519e5e784d7a3000000/Plantas-daFloresta-Atlantica-Bignoniaceae.pdf

Thiers B. 2020, continuously updated. Index Herbariorum: a global directory of public herbaria and associated staff. New York Botanical Garden's Virtual Herbarium. http://sweetgum.nybg.org/science/ih/. 21 May 2020.

Wanderley MGL. 2011. Flora da serra do cipó, Minas Gerais: Xyridaceae. Boletim de Botânica da Universidade de São Paulo 29: 69-134.

Wanderley MGL, Silva GO, Guedes JS, et al. 2013. Xyridaceae. In: Martinelli G, Moraes MA. (eds.) Livro vermelho da flora do Brasil. Rio de Janeiro, Andrea Jakobsson, Instituto de Pesquisas Jardim Botânico do Rio de Janeiro. p. 1027-1036. 